\title{
Aikuiskasvatuksen sosiaaliset funktiot
}

Rantanen, Pertti 1988. Aikuiskasvatuksen sosiaaliset funktiot. Aikuiskasvatus 8, 3. 15-19. - Artikkelissa tarkastellaan aikuiskasvatusta sosiologisen funktioanalyysin näkökulmasta. Funktiotarkastelu kohdennetaan erityisesti järjestölliseen sivistystyöhön. Aikuiskasvatus nähdään konfliktisena, vastakkaisia pyrkimyksiä ja etuja sisältävänä kenttänä. Artikkeli perustuu tekijän pro gradu-tutkielmaan (1987).

\section{Kohti kriittistä keskustelua}

Aikuiskasvatuksen merkitys on lisääntynyt voimakkaasti taloudellisten ja yhteiskunnallisten muutosten myötä. Aikuiskasvatus nähdään tämän päivän Suomessa paitsi ihmisen persoonallisen kasvun edistäjänä, yhä keskeisemmin myös työvoimalle asetettujen muuttuvien laatuvaatimusten tyydyttäjänä ja yritysten kilpailukyvyn turvaajana. Entistä useammat ovat valmiita vannomaan aikuiskasvatuksen nimeen. Yhteiskunnassa tuntuu vallitsevan laaja yhteisymmärrys aikuiskasatuksen siunauksellisuudesta.

Ominaista tälle koulutuspoliittiselle konsensus-ajattelulle on, että aikuiskasvatukseen sen vallitsessa muodostuu jonkinlainen "hyvää kaikille, ei keneltäkään pois" -ilmapiiri. Aikuiskasvatus ymmärretään säröttömänä, ristiriidattomana kokonaisuutena, jossa kysymystä eri suuntaan vievistä eduista, arvoista ja päämääristä ei hevin esitetä.

Tässä artikkelissa aikuiskasvatuksen yhtenäisyys ja jonkinlainen varaukseton yleishyödyllisyys nähdään virheellisinä lähtökohtina. Jäsentämällä aikuiskasvatusta sosiologisen funktioanalyysin välineistöllä se näyttäytyy ilmiönä, jolla on hoidettavanaan erilaisia, keskenään ristiriitaisiakin tehtäviä yhteiskunnassa.
Persoonallisuuden kehittämisen ja tietojen lisäämisen ohella aikuiskasvatus myös tukee olemassa olevien valtarakenteiden ja hallitsevan tietoisuuden säilymistä.

\section{Analyysin välineet}

Funktio merkitsee tässä yhteydessä lähinnä ilmiön olemassaolon seurausta jonkin kokonaisuuden kannalta, tuon ilmiön tosiasiallisia tehtäviä. Puhe on aikuiskasvatuksen sosiaalisista funktioista eli sen toteutuvista yhteiskunnallisista tehtävistä. Funktionaalisuutta voidaan toki tarkastella myös yksilöiden kannalta (ks. esim. Allardt 1971, 212; Liljeström 1982, 73-75). Esimerkiksi osallistuminen aikuiskasvatukseen voi tarjota mielekästä sisältöä ihmisen elämään. Samaa toimintaa voidaan kuitenkin tarkastella myös yhteiskunnallisesti, esim. ideologisena uusintamisena tai instituutioiden tunkeutumisena vapaa-aikaan.

Koulutuksen sosiaalisia funktioita ei pidä sotkea sen päämääriin. Funktioilla ei nimittäin tarvitse olla ketään suunnittelijaa. Niiden ei tarvitse olla intentionaalisia, jollaisia taas päämäärät ovat aina. (Jarvis 1985, 133-134; myös Merton 1968, 105.)

Jarvis tarkastelee aikuiskasvatuksen sosiaalisia funktioita kuuden käsitepaperin avulla. $\mathrm{Pa}$ -
Nurmi, K. 1985. Opiskelijan ja opettajan parijärjestelmä korkea-asteen etäopetuksessa. Helsingin yliopisto, Lahden tutkimus- ja koulutuskeskus.

Rekkedal, Torstein. 1972. Correspondence Studies, Recruitment, Achievement and Discontinuation. Oslo.

Rekkedal, T. 1985. Introducing the Personal Tutor/ Counsellor in Distance Education. Report 2: Final report. NKI-skolen. Stabekk, Norway.
Sewart, Keegan. Holmberg (ed. 1983). Distance Education International Perspectives. Croom Helm Ltd. Kent.

Stein, L.S. 1960. Design of a Correspondence Course. Adult Education 10, 161-166.

Wăngdahl, A. 1980. Who are the Correspondence Students and What about Their Handicap of Isolation. University of Lund, Department of Education. Padagogical Reports. Lund. 
rijako perustuu kahden sosiologisen koulukunnan ja lähestysmistavan olemassaoloon. Näistä ensimmäinen on kiinnostunut järjestyksen ongelmista ja sävyttynyt konsensus-henkisesti. Toisen lähestymistavan avainsanana taas on kontrolli ja se korostaa konfliktia yhteiskunnan perusilmiönä. Edellinen näkökulma kiinnittää huomionsa etupäässä yhteiskunnan rakenteeseen, jälkimmäinen taas yhteiskunnan toimijoihin ja heidän vuorovaikutukseensa. (Jarvis 1985, 58; konfliktisesta ja konsensusparadigmasta ks. myös Dahrendorf 1969, 211-220.)

Kummankin paradigman mukainen tulkinta aikuiskasvatuksen funktioista voi Jarvisin mielestä olla aivan yhtä "oikea", olkoonkin, että tulkinnat ovat aivan erilaisia (Janis 1985, 134135). Tätä mieltä on myös Dahrendorf, jonka mukaan ei "integraatioteoriaa" eikä "pakkovaltateoriaa" voi kumpaakaan yksin pitää riittävänä sosiologisissa yhteyksissä. Ne ovat pikemminkin rinnakkaisia ja toisiaan täydentäviä viitekehyksiä, eivät vaihtoehtoja toisilleen. Kysymys on sosiaalisen rakenteen kaksista erilaisista kasvoista. (Dahrendorf 1969, 218-220.)

Jarvisin jaottelun perusteella aikuiskasvatuksen sosiaaliset funktiot voidaan esittää kuuden käsiteparin avulla seuraavasti:

konsensus-paradigma konflikti-paradigma

- sosiaalisen järjestel- — olemassa olevien män ylläpito sosiaalisten suhtei-

— tiedon siirto den reproduktio

duktio

— yksilöllinen edisty- _ valikointi minen

— "toinen mahdolli- _ legitimaatio suus"

- vapaa-ajan harras- _ instituutioiden ekstus

- kehitys pansio työn ulkopuoliseen aikaan

(Jarvis 1985, 134-135)

Seuraavissa luvuissa pyritään aikuiskasvatuksen mahdollisia tehtäviä hahmottamaan em. käsitepareja apuna käyttäen.

\section{Sosiaalisen järjestelmän ylläpito - sosiaalisten suhteiden reproduktio}

Koulutus seuraa yhteiskunnan muutoksia. Aikuiskasvatuksen tehtävänä on sosiaalistaa ihmisiä nopeasti muuttuvan yhteiskunnan uusiin olosuhteisiin ja rooleihin. Tästä ammatillinen aikuiskoulutus on hyvä esimerkki. Toisaalta se ei kuitenkaan puutu rakenteisiin. Se vain sopeuttaa ihmisiä muutoksiin ja kvalifioi työvoimaa teknologisen kehityksen luomiin muuttu- viin tarpeisiin.

Ammatillinen aikuiskasvatus voidaan siis "nähdä mekanismina, joka edistää sosiaalisen järjestelmän säilymistä ja uusintaa tuotannon yhteiskunnalliset suhteet". (Jarvis mt: 136137.)

Sosiaalinen uusintaminen eli reproduktio ei kuulu kuitenkaan yksinomaan ammatilliselle aikuiskasvatukselle. Jos sosiaalista reproduktiota ajatellaan työvoiman uusintamisen lisäksi myös laajemmasta näkökulmasta, ulottuu keskustelu myös ei-ammatilliseen aikuiskasvatukseen. Voidaanhan nimittäin ajatella että koulutuksella kykyjen ja taitojen lisäksi kasvatetaan ihmisiä sosiaalisten suhteiden pysyttämisen kannalta tarpeelliseen moraaliin ja arvostuksiin. Parconsin näkemys koulutuksen tehtävästä tuottaa paitsi "capacities", myös "commitments" merkitsee nähtävästi juuri tätä (Parsons 1961, 435). Kykyjen ja valmiuksien lisäksi tuotetaan myös moraalista ja henkistä sitoutumista vallitseviin oloihin.

\section{Tiedon siirto - kulttuurinen reproduktio}

Aikuiskasvatuksessa siirretään tietoa. Sen "siirtäminen" ei vielä sinänsä määrittele aikuiskasvatuksen toteuttamaa funktiota. Marxiin tukeutuen Jarvis sanoo, ettei tieto eikä se laajempi kulttuuri, jota kasvatuksessa siirretään, ole neutraalia. Ne vain näyttävät siltä. Tämä näennäinen neutraalius taas on ilmausta hegemonian ${ }^{1)}$ toimintatavasta. (Jarvis 1985, 138.)

Bourdieun ja Passeronin tavoin voidaan ajatella aikuiskasvatuksen koulujärjestelmän lailla heijastavan lähinnä hallitsevan kulttuurin ja hallitsevien ryhmien arvoja. Näin hallitsevista ryhmistä tulevat opiskelijat hyötyisivät myös aikuiskasvatuksesta enemmän kuin esimerkiksi taustaltaan työväenluokkaiset osallistujat. (Bourdieu - Passeron 1977 esim. 42-46, 48-52.) Tämä selittäisi Jarvisin ja Thompsonin havaitseman aikuiskasvatuksen keskiluokkaisuuden (Jarvis 1985, 139; Thompson 1980, $21-25)$.

Keskiluokkaisuuteen yhteydessä olevaan osallistumisrakenteeseen vääristymään ovat huomiota kiinnittäneet myös suomalaiset aikuiskasvatuksen tutkijat. Aikuisopinnothan näyttävät kasautuvan niille, joilla jo ennestään on koulutusta. (Esim. Lehtonen \& Tuomisto 1973, 286-287; Katajisto 1984, 63-66).

1) Hegemonia on käsite, joka Gramscilla perustuu hänen käsitykseensä yhteiskunnan päällysrakenteen jakautumisesta kahteen osaan: valtioon ja kansalaisyhteiskuntaan. Valtio ilmentää suoraa valtaa ja pakolla alistamista. Hegemonia taas toimii kansalaisyhteiskunnan tasolla. Se voidaan määritellä tilanteena, jossa "suuret joukot antavat 'spontaanin' kannatuksensa suunnalle, jonka hallitseva perusryhmä on antanut yhteiskuntaelämälle" (Gramsci 1979: 129-130). Voimakeinøjen käyttöä hallinnan apuna ei enää tarvita. 


\section{Yksilöllinen edistyminen — valikointi}

Ammatillinen aikuiskasvatus voidaan nähdä yksilölliselle tarjoutuvana mahdollisuutena edetä omalla työurallaan. Konfliktisesta perspektiivistä sama asia näkyy valikointina: Yksilöllisten urakehitysväylien näennäinen avoimuus ja koulutuksen kautta mahdollistuva sosiaalinen liikkuvuus voivat myös legitimoida olemassa olevaa valtasuhteiden järjestelmää. (Jarvis 1985, 139.)

\section{Toinen mahdollisuus — legitimointi}

Konsensus-paradigman mukaisesti aikuiskasvatus tarjoaa koulunsa päättäneelle aikuiselle toisen mahdollisuuden hankkia itselle uusi rooli yhteiskunnassa, esimerkiksi paremmin palkattu tai mielenkiintoisempi ammatti. Tässä mielessä aikuiskasvatus tavallaan antaa aikuisille tilaisuuden "aloittaa alusta".

Konflikti-paradigman perusteella voidaan kuitenkin väittää, että aikuiskasvatus antaessaan mahdollisuuden yhteiskunnallisen aseman muuttamiseen myös luo harhakuvan mahdollisuuksien tasa-arvosta. Samalla se tukee vallassaolijoita legitimoimalla näiden valta-aseman koulutuksessa menestymisen oikeutettuna seurauksena.

Aikuiskasvatus antaa "toisen mahdollisuuden" vain olemassaolevan rakenteen puitteissa. Näin aikuiskasvatus myös ylläpitää hallitsevien luokkien/ryhmien hegemoniaa. (Jarvis 1985, 143-145.)

\section{Vapaa-ajan harrastus - instituutioiden ekspansio}

Aikuiskasvatus on hyvin monille ihmisille vapaa-ajan harrastus, tapa käyttää työn ulkopuolista aikaa. Jarvisin mukaan tulee kuitenkin pitää mielessä, että vaikka tämä olisikin aikuiskasvatuksen ilmifunktio, on sen piiloinen funktio kuitenkin säilyttää sosiaalisen järjestelmän stabiilisuus sinä aikana, jona ihmiset eivät täytä aikaansa ja ajatuksiaan työllä. Eli "kasvatus laajenee täyttämään sen aukon, jossa työn vaatimuksia ei enää esiinny" (Jarvis 1985, 147).

Vapaaehtoista opiskelua voidaan pitää myös luokkasidonnaisena vapaa-ajan vieton tapana, eräänlaisena tyylikysymyksenä. Aikuiskasvatusta voidaankin tarkastella Bourdieun teorian mukaisena "kenttänä", jolla selviäminen edellyttää juuri tälle kentälle tunnusomaista kulttuurista pääomaa. Toisilla yhteiskuntaryhmillä tätä pääomaa on, toisilla ei. (Jarvis 1985, 145; Bourdieu 1985,105-110.)
Käsityksiä aikuiskasvatuksesta ylempien yhteiskuntaryhmien kenttänä ja vapaa-ajan vieton tyylinä tukevat myös Bergstenin havainnot. Hän tutki Ruotsissa vähän koulutettujen ihmisten osallistumista aikuiskasvatukseen. Hän tuli siihen tulokseen, että osallistuminen vapaaajalla tapahtuvaan, ei-pätevöittävään aikuiskasvatukseen on yleisintä niiden keskuudessa, jotka ovat myös aktiivisia järjestöihmisiä ja joiden vapaa-ajan viettoa luonnehtivat paremmin koulutetuille tyypilliset kulttuuriharrastukset: museoissa ja näyttelyissä käynti, lukeminen, teatteri ja konsertit. (Bergsten 1977, 134-136.)

Aikuiskasvatuksella on myös sosiaalinen funktio työttömien jatkuvan vapaa-ajan täyttämisessä. Se tarjoaa heille edes jotakin tekemistä toimettomuuden sijaan. (Jarvis 1985, 146.) Tässä mielessä aikuiskasvatukseen pätee Gunnar Adler-Karlssonin arvio koulusta "tarpeettomien pysäköintipaikkana", jossa ne ihmiset, joita tuotantoelämä ei tarvitse, ovat säilössä ja valvonnan alaisina puuhailemassa asioita, joilla sinänsä ei ole niin kovin paljon merkitystä (Adler-Karlsson 1984). Työllisyyskoulutus silloin, kun sillä ei ole muuta virkaa kuin pitää nuorisotyöttömät poissa kaduilta, on tästä hyvä esimerkki. Yhteiskuntarauhan kannalta se voi olla mielekästä, mutta saattaa vaikuttaa kohtalokkaasti "koulutettavien" sosiaalistumiseen. (Maljojoki 1987).

\section{Kehitys - vapauttaminen}

Opiskelijan persoonallisen kehittymisen edistämistä voidaan pitää aikuiskasvatuksen yhtenä funktiona. Jarvis puolestaan pitää sitä lähinnä kasvatuksen tavoitteena. Hän huomauttaa myös siitä, että se, mikä näyttää ihmisten kehittämiseltä, voikin itse asiassa olla heidän sopeuttamistaan järjestelmän heille tarkoittamille paikoille. (Jarvis 1985, 147-148.)

Freire (1982) näkee kasvatuksen voivan olla luonteeltaan paitsi hallitsevien ryhmien intresseistä lähtevää tiedonsiirtoa, myös vapauttavaa, yhteiskunnan alistetussa asemassa olevien ihmisten tietoisuuden herättämistä.

\section{Aikuiskasvatus ja sosiaalipolitiikka}

Edellä olevaa Jarvisin jaotteluun perustuvaa esitystä aikuiskasvatuksen yhteiskunnallisista tehtävistä täydentää Griffinin ajatus aikuiskasvatuksen ja sosiaalipolitiikan läheisestä yhteydestä. Griffin katsoo, että aikuiskasvatusta tulisi tarkastella sosiaalityön tavoin sosiaaliseen kontrolliin liittyvien tehtäviensä näkökulmasta. Aikuiskasvatus suuntautuu nimittäin eräänlaisena kompensaationa niihin ihmisryhmiin, joita yhteiskunnassa riistetään ja alistetaan. Se 
luo yhteiskunnallista stabiilisuutta, legitimoi hallitsevia normeja ja sulauttaa mahdollisia vastarinnan lähteitä olemassa olevaan järjestykseen. (Griffin 1983, 226.)

Yhteys sosiaalipolitiikkaan näkyy aikuiskasvatuksessa myös suhteessa yhteiskunnalliseen muutokseen. Sosiaalipolitiikalle on Griffinin mielestä luonteenomaista se, että se luo illuusioita muutoksista silloinkin, kun mitään todellista muutosta ei ole tapahtunut. Aikuiskasvatus voi luoda samanlaisia harhakuvia. (Griffin 1983, 232-233.)

Aikuiskasvatuksen laaja tarjonta erilaisissa tunne-elämän ja virkistyksen alueille kuuluvissa opintoaineissa on sosiaalisesti funktionaalista, koska se integroi yhteiskuntaan sellaisia ihmisiä, jotka urbaani elämä tekisi yksinäisiksi, onnettomiksi, vieraantunteiksi ja sosiaalisesti huonovointisiksi (Griffin 1983, 230). Näin esimerkiksi sellaiset aihepiirit kuin ihmissuhdekysymykset, parapsykologia, astrologia tai askartelu, joiden arvoon aikuiskasvatuksen sisältöinä mm. Alanen (1985b) suhtautuu kriittisesti, saattavatkin olla yhteiskunnallisesti funktionaalisia toimintoja luodessaan ainakin subjektiivisesti koettua mielekkyyttä ihmisten elämään.

\section{Työväen Sivistysliiton opintotoiminnan tehtävät}

Tämän artikkelin pohjana olevassa opinnäytetyössä sovelletaan edellä esitettyä funktioanalyyttistä tarkastelukehikkoa Työväen Sivistysliiton (TSL) toteuttaman opintotoiminnan tutkimiseen. Järjestön aikuiskasvatuksen yhdeksi keskeiseksi funktioksi hahmottuu työväenliikkeen järjestöjen sosiaalisten rakenteiden uusintaminen. Tämä tapahtuu pitkälti järjestötehtävien hoitajia kouluttamalla.

Järjestökoulutuksessa piilee kuitenkin järjestöjen sisäisen demokratian kannalta myös vaara: mitä enemmän opintotoiminta suuntautuu järjestöjen toiminnan pyörittämisessä tarvittavan aktivistijoukon kouluttamiseen nk. rivijäsenistön kouluttamisen kustannuksella, sitä herkemmin koulutus myös luo ja ylläpitää järjestöjen sisäisten suhteiden hierarkkisuutta.

TSL:n toimintapiirissä tapahtuvassa sivistystyössä näkyy myös piirteitä siitä, että opintotoiminnassa siirretään arvostuksia ja hallitsevaa tietoisuutta ylhäältä alas eli hoidetaan kulttuurisen reproduktion tehtävää. Sivistysjärjestön yhdessä jäsenjärjestöjensä kanssa toteuttamien opintokampanjoiden perustana ovat yleensä palkattujen työntekijöiden ja huippuaktiivien järjestöjen koulutustarpeita koskevat arviot. Tällöin on olemassa se vaara, että niistä ihmisistä, joille opinnot on tarkoitettu, tulee lähin- nä toiminnan kohteita. Heillä ei ole mahdollisuutta vaikuttaa opintojen arvoja, päämääriä tai sisältöjä koskeviin ratkaisuihin.

Myös opintotoiminnan tehtävästä toimia vapaa-ajan täyttäjänä ja sosiaaliterapeuttisen tehtävän hoitajana on viitteitä nähtävissä. Esimerkiksi TSL:n alaisuudessa tapahtuvan varsin mittavan eläkeläisten opintotoiminnan sosiaalisena tehtävänä voidaan pitää toimintaan osallistuvien vapaan ajan täyttämistä - riippumatta mitenkään kerholaisten omien opintopyrkimysten vakavuudesta. Kerhotyö on sosiaalisesti funktionaalista siksi, että se osaltaan pitää eläkeläiset työn siteiden katkettua edelleen organisoidussa toiminnassa, kiinni yhteiskunnassa.

Osoituksia myös vapauttavista ja kriittistä tietoisuutta edistävistä elementeistä löytyy. Näistä mainittakoon 1980-luvun puolivälissä käynnistynyt sivistysjärjestön organisoima laaja tietotekniikkaan ja sen yhteiskunnallisiin vaikutuksiin keskittyvä kurssitoiminta ja opintoaineistotuotanto. 80-luvun alkupuolella liikkeelle lähteneissä ihmissuhdetietouden, elämäntavan ja ilmaisuvalmiuksien opintoprojekteissa on samansuuntaisia piirteitä.

Kaikkiaan Työväen Sivistysliiton opintotoiminnassa tulee esiin useampia mahdollisia sosiaalisia funktioita. Osa niistä on selkeästi ristiriidassa keskenään. Syytä on kuitenkin muistaa, ettei Työväen Sivistysliittoa - eikä muitakaan organisaatioita - ole viisasta katsella monoliittisena kokonaisuutena. Järjestön sisällä ja sen toimintakentässä on erilaisia pyrkimyksiä, jotka ohjaavat toteutuvaa opintotoimintaa. Olemassa olevan järjestyksen säilyttäminen ja ihmisten kriittisen tietoisuuden kasvattaminen voivat ainakin jossakin määrin toteutua saman organisaation puitteissa. Rajan vetäminenkin on usein vaikeaa: esimerkiksi luottamusmieskoulutuksessa on varmasti kysymys kummastakin. Toisaalta samoista ihmisistä koulutetaan sopimusjärjestelmän toteuttajia, toisaalta myös työntekijöiden etujen ajajia.

Se, että sivistysjärjestön opintotoiminta toteuttaa erilaisia tehtäviä, ei kuitenkaan tarkoita, että sisällöltään vastakkaiset funktiot eläisivät sovussa rinnakkain. Pikemminkin ne käyvät (ja niistä käydään) kamppailua, jossa jotkut ovat niskan päällä, toiset taas häviöllä. Kamppailun tilanne määrittää sitä, millainen suhteellinen asema eri funktioilla on sivistystyössä. Kaikkiaan kysymys sivistysjärjestön kuten koko aikuiskasvatuksenkaan toteuttamista yhteiskunnallisista tehtävistä ei ole mitenkään yksinkertainen. Esimerkiksi se, tarkastellaanko ongelmaa konsensuksen vai konfliktin sävyttämästä näkökulmasta, johtaa eri tulkintaan samasta materiaalista. 


\section{Lähteet}

Adler-Karlsson, Gunnar 1984. Koulu - pysäköimispaikka tarpeettomille vai tie sisäiseen avartumiseen? Suomennos Arto ja Kirsti Angervo. Helsinki.

Alanen, Aulis 1985. Tehokas palvelu aikuiskasvattajan ammatti-ideaalina. Teoksessa Manni, Eeva- Tuomisto, Jukka (toim.): Humanistin teemojen tuntumassa. Acta Universitatis Tamperensis, ser A vol 196.

Allardt, Erik 1971. Yhteiskunnan rakenne ja sosiaalinen paine. Porvoo.

Bergsten, Urban 1977. Adult Education in Relation to Work and Leisure. A Cross-sectional Study of Adults with Short Previous Formal Eductaion. Stockholm Studies in Educational Psychology 22.

Bourdieu, Pierre 1985. Sosiologian kysymyksiä. Suomennos J.P. Roos. Jyväskylä.

Bourdieu, Pierre - Passeron, Jean-Claude 1977. Reproduction in Education, Society and Culture. Beverly Hills - London.

Dahrendorf, Ralf 1969. Luokat ja luokkaristiriidat teollisessa yhteiskunnassa. Suomennos Ilse Koli. Porvoo.

Freire, Paulo 1982. Pedagogy of the Oppressed. 9. painos. Bungay, Suffolk.

Gramsci, Antonio 1979. Vankilavihkot. Toimittanut Mikael Böök. Suomennos: Matti Berger, Mikael Böök ja Leena Talvio. Helsinki.
Griffin, Colin 1983. Social Control, Social Policy and Adult Education. International Journal of Lifelong Education 3.

Jarvis, Peter 1985. The sociology of adult \& continuing education. Worcester.

Katajisto, Jukka 1984. Osallistumismuutokset Suomen aikuiskasvatuksessa 1972-1980. Aikuiskasvatus 2 .

Lehtonen, Heikki - Tuomisto, Jukka 1973. Aikuiskoulutus Suomessa: käsitykset ja käyttö. Tampereen yliopiston tutkimuslaitos. Tutkimuksia A 45 .

Liljeström, Rita 1982: Varttumisen ehdot. Suomennos Virve Kajaste. Helsinki.

Maljojoki, Pentti 1987. Yhteiskuntakehitys ja nuorten koulutuksen kysyntä - Kuljemmeko koulutusoptimismista koulutuspessimismiin? Kasvatus 2.

Merton, Robert K. 1968. Social Theory and Social Structure. New York.

Parsons, Talcott 1961. The School Classa as a Social System. Some of Its Functions in American Society. Teoksessa Halsey A.H. - Floud, Jean - Anderson, C. Arnold (Eds.). Education, Economy and Society. Chicago, Illinois.

Rantanen, Pertti 1987. Sivistysjärjestö aikuiskasvatuksen organisaationa. Työväen sivistysliiton opintotoiminnan kasvatussosiologinen tarkastelu. Helsinki.

Thompson, Jane L. 1980. Introduction. - Thompson, Jane L. Adult Education for a Change. Tiptree, Essex. 
Rantanen, Pertti. 1988. The Social Functions of Adult Education

The article examines adult education from the viewpoint of sosiological functional analysis. This is particularly directed at liberal education carried out by organizations. Adult Education is seen as a sector with conflicting aims and benefits. 